Portland State University

PDXScholar

1979

\title{
Some physical and biological factors affecting red- tailed hawk productivity
}

Stewart Wayne Janes

Portland State University

Follow this and additional works at: https://pdxscholar.library.pdx.edu/open_access_etds

Part of the Biology Commons, and the Population Biology Commons Let us know how access to this document benefits you.

Recommended Citation

Janes, Stewart Wayne, "Some physical and biological factors affecting red-tailed hawk productivity" (1979). Dissertations and Theses. Paper 2797.

https://doi.org/10.15760/etd.2793

This Thesis is brought to you for free and open access. It has been accepted for inclusion in Dissertations and Theses by an authorized administrator of PDXScholar. Please contact us if we can make this document more accessible: pdxscholar@pdx.edu. 
AN ABSTRACT OF THE THESIS OF Stewart Wayne Janes for the Master of Sclence in Biology presented November 21, 1979

Title; Some Physical and Biological Factors Affecting Red-tailed Hawk Productivity.

APPROVED BY MEMBERS OF THE THESIS COMMITTEE;

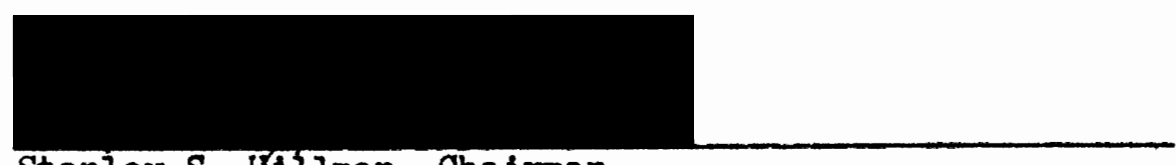

Stanley S. Hillman, Chairman

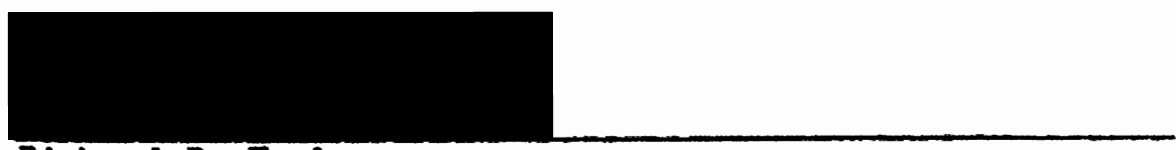

Richard $B_{\text {. Forbes }}$

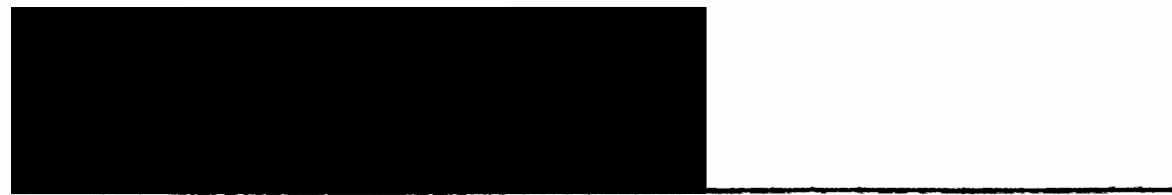

Robert 0. Tinnin

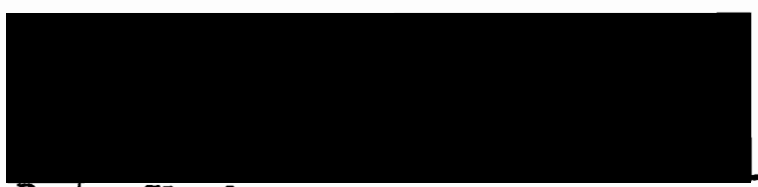

Deane Clarkson

Various physical and biological factors affecting annual productivity in a Red-tailed Hawk population in north-central Oregon were investigated. The percentage of the population successfully fledging one or more young was the most important factor in determining the number of young fledged per pair in a given year. Neither clutch size 
nor the number of young fledged per successful nest varled significantly. Percent pair success was correlated with several January weather variables. A cold and dry January is positively correlated with Red-talled Hawk productivity. This is apparently related to the onset of rapid vegetative growth, and this in turn is positively correlated with the timing of the emergence and reproductive cycle of the princlpal prey, Belding's and Townsend's ground squirrels, (Turner 1972). Because a cold and dry January delays the emergence of ground squirrels, the period of emergence and dispersal of the young squirrels more closely corresponds to the time of peak food needs of the young Red-tailed Hawks, and greater pair success is observed. This relative abundance of prey appears to be of greater importance than actual abundance.

Red-talled Hawk productivity was found to correlate significantly with two habitat variables: the presence of adequate numbers of dispersed hunting perches and relative ground squirrel abundance. The presence of one or more perches per sixteenth section provided the best single correlation. Nelther territory size nor competition from interspecifically territorial Swainson's Hawks were correlated with productivity of Red-talled Hawk territorles. Red-talled Hawks with Inhabited dwellings within their territories fledged significantly more young than those without. 
SOME PHYSICAL AND BIOLOGICAL FACTORS AFFECTING

RED-TAILED HAWK PRODUCTIVITY

\author{
by \\ STEWART WAYNE JANES
}

A thesis submitted in partial fulfillment of the requirements for the degree of

MASTER OF SCIENCE

in

BIOLOGY

Portland State University

1979 
TO THE OFFICE OF GRADUATE STUDIES AND RESEARCH,

The nembers of the Comittee approve the thesis of

Stewart Wayne Janes presented November 21, 1979.

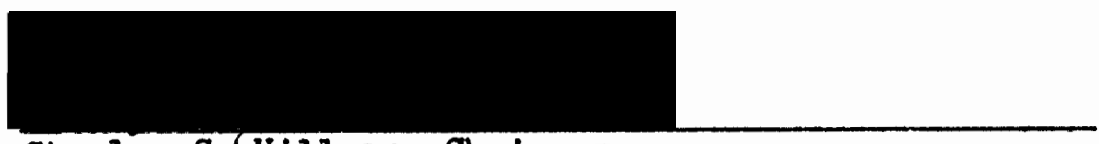

Stanley S. Hillman, Chairman

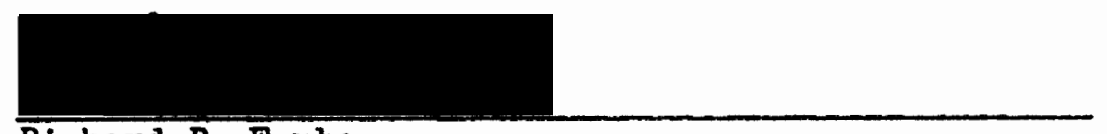

Richard B. Forbes

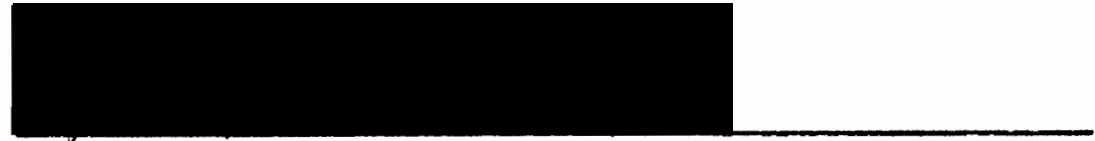

Robert 0. Tinnin

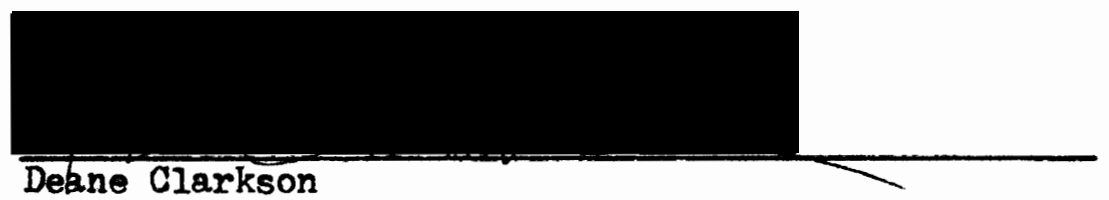

APPROVED:

W. Herman Taylor, Head, Degatent of Biology

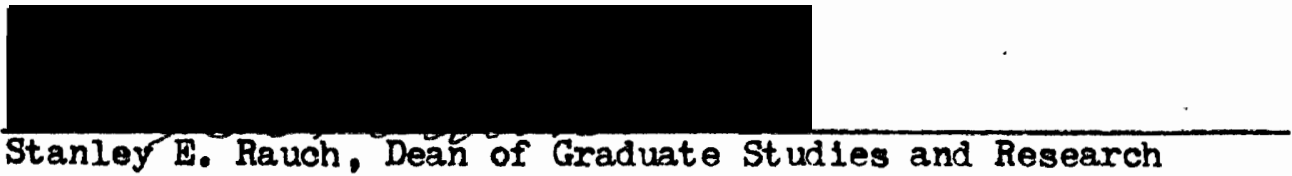


TABLE OF CONTENSS

PAGE

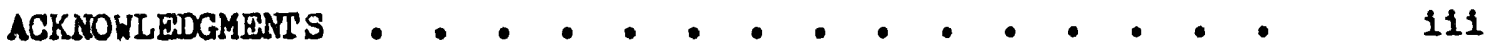

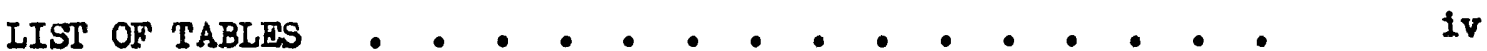

LIST OF FIGURES • • • • • • • • • • • • • • •

CHAPTER

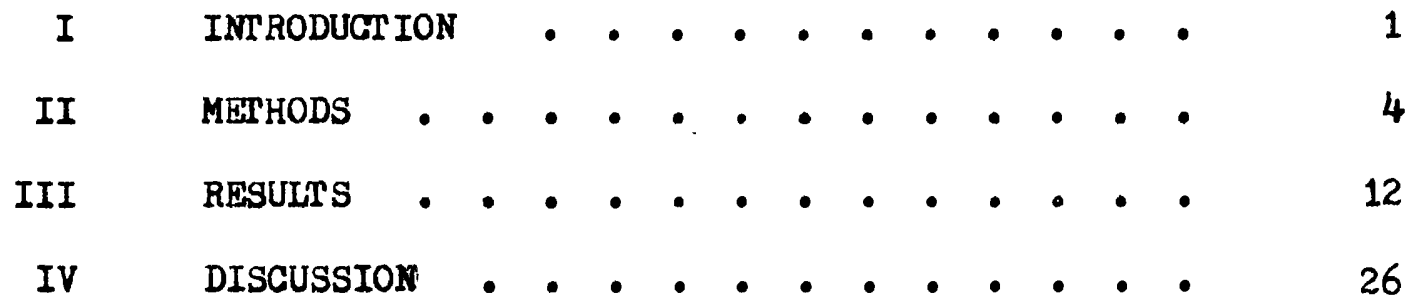

Litgrature Gited • • • • • • • • • • • • 36 


\section{ACKNOWLEDGMENTS}

First, I would like to thank all the people that shared both cold fingers and sonetines tedious, sometimes exhilarating hours in the field, Rose Adalr, Chris Corrigan, Vern Dipletro, Christy Galen, Debra Peterson Janes, Pete Krinke, Dave McClain, David Schulman, Gary Vonada, and Joanne Vrilakis. In particular, I want to thank John Barss who has been with the project from the beginning. I would also like to extend my appreciation to all the landowners that permitted me access to their land. Thanks also go to Dr. Stan Hillman and the rest of the committees Dr. Richard Forbes, Dr. Robert Tinnin, and Dr. Deane Clarkson for their assistance in bringing this stage of the project to a successful conclusion. Special thanks go to Rich Steeves for his valuable contributions, Darey Shell for her aid with the computer, and my wife, Deb, for her support through the final stages of the project. Finally, I wish to extend my gratitude to the Portland Audubon Society and the Oregon Environmental Foundation for their financial support. 
IIST OF TABIES

TABLE

PAGE

I Summary of Red-tailed Hawk territory productivity . •

II Red-tailed Hawk annual productivity measures for 1973-1979 . . . . . . . . . . . .

III Red-tailed Hawk food habits determined from orey remains found at the nest and prey observed captured . . . . . . . . . . . . . .

IV Simple linear regression analyses of Red-tailed

Hawk anmul productivity to weather correlations for 1973-1979 . . . . . . . . .

$\checkmark$ Simple linear regression analyses of Red-tailed Hawk percent pair success to weather correlations for 1973-1979 . . . . . . . . .

VI Simple linear regression analyses of Red-tailed Hawk annual productivity and percent pair success to weather correlations for 1973-1978..

VII Simple linear regression analyses of Red-tailed Hawk territory productivity to habitat correlations . . . . . . . . . . . .

VIII Step-wise multiple linear regression analyses of Red-tailed Hawk territory productivity to habitat correlations . . . . . . . . . 


\section{LIST OF FIGURES}

FIGURE

PAGE

1. Red-talled Hawk and Belding's ground squirrel reproductive chronologies 
CHAPTER I

\section{INTRODUGTION}

Productivity, the number of young fledged per pair or territory per breeding season, varles significantly in many avian populations. Both annual and interpair variation have been observed and have been attlbuted to a number of factors. Review papers pertaining to clutch size and certain other aspects of productivity are presented by Lack (1947, 1948), Klomp (1970), and Hussell (1972).

Little work has been conducted on variation in productivity of raptors. Because raptors are relatively long-lived species, they have the evolutionary option of varying reproductive effort more than shortlived passerines. This flexibility can present a greater source of varlation in productivity and may permit a closer correlation of productivity with the prevaling environmental conditions. Raptors also occupy a position high on the food chain. If raptors are energy-limited, their position would make them comparatively sensitive to variab1lity in their food supply. Therefore, energet ic factors influencing productivity may be more easily discerned. The few studies that have investigated this problem in detail within a raptor population include Cave (1968) with the Kestrel (Falco tinnunculus) and Southern (1970) with the Tawny Owl (Strix aluco).

Significant annual variation in raptor productivity has been noted in several studies (Cave 1968, Fitch et al., 1946, Houston 1975; 
Lack 1947, 1948, McInva1lle and Keith 1974; Mebs 1964; Pitelka et al.. 1955; Schmaus 1938; Southern 1970; Tubbs 1967; USDI 1979). In contrast, other studies have found no apparent variation (P1cozzi and Wier 1974, Smith and Murphy 1973). Several factors, particularly food abundance, appear to be important. Food abundance has been observed to operate at various stages in the reproductive cycle. It has been correlated with non-breeding (Houston 1975; Pitelka et al. 1955; Southern 1970), clutch size (Cave 1968, Houst on 1975; Lack 1947, 1948; McInvaille and Keith 1974; Mebs 1964; Schmaus 1938; Southern 1970), nest desertion (Cave 1968; Southern 1970), and loss of young (Lack 1947, 1948; Mebs 1964; Schmaus 1938; Southern 1970). Weather has been correlated with productivity, but except for the study of McInvaille and Keith (1974) in which nestlings were killed directly by inclement weather, this relationship has been only indirectly related to productivity through the impairment of the hunting ability of the parents (Cave 1968; Southern 1959,1970$)$. Annual variations in productivity have also been ascribed to population density (Cave 1968), laying date (Cave 1968), and predation (Fitch et al., 1946; Hagar 1957; McInvaille and Ke1th 1974).

Variations in interpair productivity have been less studied. Southern (1970) inferred that the age of the birds - at least of the male, which does most of the hunting - may be correlated with productivity. The time of laying (Cave 1968), habitat at a general level. (Southern 1970; Olendorff and Stoddart 1974; Picozz1 and W1er 1974), and competition through density (Southern 1970) have also been cor- 
related with territory productivity.

It is the intent of this work to investigate various physical and biological factors affecting both annual and interterritorial productivity in a Red-tailed Hawk population. Factors studied include structural and biological habitat features, weather, and competition. Red-tailed Hawks were chosen for this study as they are easily observed and territories are easily delimited. Predation, density, and laying date - potentially complicating sources of variability in productivity were not found to vary in this population, permitting more direct study of the factors in question. 


\section{CHAPT ER II}

\section{METHODS}

The study area covers 124 square kilometers in the shrub-steppe region of north-central Oregon. The site encompasses a broad valley with rolling hills and is drained by three small creeks. Rinrock-lined canyons are found in some areas. Elevations range from 677-1308m. The land is used prinarily for the grazing of cattle and dryland farming of wheat. The natural vegetation is characteristic of the Columbia Basin province as described by Franklin and Dyrness (1973). The dominant associations include big sage (Artemisia tridentata)/bluebunch wheatgrass (Agropyron spicatum) and bluebunch wheatgrass/Idaho fescue (Festucca Idahoensis). A Iong history of grazing, however, has reduced the abundance of the perennial grasses, and such species as cheatgrass (Bromus tectorum) and gray rabbitbrush (Chrysothamnus nauseosus) are now ubiquitous. Junipers (Juniperus occidentalis) are the only trees of any abundance on the area and are locally common. Black poplars (Populus nigra) and black locusts (Robina pseudo-acacia) are found around many of the dwellings including abandoned homesteads.

The study was conducted from 1973 through 1979 with most of the fleld work conducted from March through June each year. During this time Red-tailed Hawks were observed in order to detetermine density, territorial boundaries, reproductive outcome, and behavior associated with territoriality and the reproductive effort. 
Territory is defined as the area defended by or regularly occupied by a pair. This definition is similar to the definition of "utilized territory" of Odum and Kuenzler (1955). A "regularly occupied" area is defined as an area for which there is more than one observation. This definttion includes areas for which no active defense was noted (resulting for the most part from a lack of intruders). Pairs existed that shared no boundary with another Buteo, and whose area, therefore, could not be considered defended.

All observations were recorded on fleld maps as a flight line and/or perching. Date, time, individual, and incidence of territorial defense were noted. These field maps were then compiled to delinit territory boundaries. Territories were then used as they existed after the arrival of the Swainson's Hawk (Buteo swainsoni) for the following analyses. Territorial boundaries were most accurately determined in 1977 and 1978 and were the ones used.

Though Red-tailed Hawks are comparatively tolerant of nest visits by investigators after the young have hatched (personal observation; Luttich et al., 1971), disturbance was kept to a minimum when determining productivity. A single visit to the nest vicinity was made, if necessary, when the young were between three and four weeks old. At this age young do not attempt to flee the nest nor are they likely to be deserted by the parents. Young present at this time were assumed to survive until fledging. This is based on my experience that no mortality other than attributable to man has been observed among nestlings between three weeks of age and fledging in any of the approximately 50 nests followed through fledging on or adjacent to the study area. Age 
of the young was estimated, and any prey remains were noted at this time. Laying date was calculated assuming a 32-day incubation period (Lutt1ch et a1., 1971). If the nest was undefended, it was examined to note any evidence of eggs or young that would aid in determining the tine and cause of fallure.

Several measures of productivity are used in this paper. One is annual productivity. This is defined as the number of young fledged per pair per breeding season. Those pairs whose reproductive outcome was altered directly by human activity are either eliminated, if disturbed prior to the young reaching three weeks of age, or considered fledged if older. Other measures relating to annual productivity include percent pair success, young fledged per success, and clutch size. A pair was considered successful if it fledged one or more young. Little information was gained regarding average clutch size because of the caution exercised in the nest vicinity. A measure was attempted using unhatched eggs found plus young observed. The resulting measure of clutch size is necessarily a minimum because of the potential disappearance of eggs or young prior to the nest visit.

Another productivity measure was that of territory productivity. This figure is the average productivity for a given territory during the period of the study. Territorles are used as opposed to pairs, as not all territorles were occupied continuously. Territory occupancy is as much a part of the measure of a territory's quality as the number of young fledged. However, because of the incomplete data for many of the territories and the great variance in annual productivity, a compensating figure was needed. Territory productivity was measured by sub- 
tracting the annual average territory productivity for a given year from an individual territory's productivity. This is done for each year there is data for a territory. An average is then calculated from the resulting differences. This average difference is the average number of young fledged above or below the seven-year average. The corrected territory productivity is this difference added to the seven-year average territory productivity.

Food habits were determined from observed captures and by prey remains found at the nest site. Prey weights were determined from specinens captured on the study area, museum specimens, and the literat ure.

Climatological data used to test the possible effects of weather upon Red-tailed Hawk productivity were obtained from the National Oceanic and Atmospheric Administration (NOAA) Antelope $1 \mathrm{~N}$ station. The Antelope 1N station (moved in late $19781.6 \mathrm{~km}$ south) is the only NOAA station located on the study area. Variables derived from these data were selected for their potential relationships to both direct and indirect effects upon Red-talled Hawk annual productivity. The direct effects upon the Red-tailed Hawk Include the perlod of egg-laying and incubation. Three kinds of variables pertain to indirect effects? (1) previous growing season effects upon the principal prey specles, (2) summer weather effects on the onset of estivation of the principal prey species, and (3) fall and winter effects on vegetative growth and emergence from hibernation of the principal prey species. The variables are self-explanatory except for 174 degree date. It was developed as a potentially better temperature variable in predicting 
vegetative growth than January temperature. The variable, 174 degree date, is the day from January 1 each year where the summed dally degrees above freezing reached 174. It is figured as follows:

$$
174 \text { degree date }=\mathrm{d}
$$

when

$$
\sum_{d=1}^{365}\left(\bar{x}_{d}-32\right) \text { 174. If } \bar{x}_{d}<32 \text {, then } \bar{x}_{d}-32=0
$$

where: $d=$ the day of the year from January 1

$$
\bar{x}_{d}=\text { the average temperature of day } d \text { in }{ } \text {. }
$$

The number 174 was selected by using half the maximum reached by the flrst olght weeks of the warmest year. Ground squirrels have emerged from hibernation by the end of February even in the coldest of winters. All varlables were tested against annual productivity and its component parts through simple linear regression and step-wise multiple linear regression. Annual productivity and its component parts were first tested for significant annual variation by one-way analysis of variance. Component parts of annual productivity were also tested against annual productivity by means of correlation. The level of significance for all tests here and following is set at the $95 \%$ confidence interval.

Habitat composition was determined by dividing the study area into 768 sixteenth sections based on township and section boundaries. Parameters measured within each sixteenth section include the number of junipers in each of three height classes $(<2 \mathrm{~m}, 2-5 \mathrm{~m},<5 \mathrm{~m})$, the number of utility poles and poplars, the dominant plant specles, topography, and the presence or absence of the followings Belding's ground squir- 
rels (Spermophilus belding1), Townsend's ground squirrels (Spermophilus townsendii), springs, streams, inhabited dwellings, and cliffs. Topography was measured by counting the number of contour lines crossed by a circle inscribed within each sixteenth section. USGS topographic maps were used with a contour interval of $6.1 \mathrm{~m}$. In addition to noting the presence of Belding's and Townsend's ground squirrels, abundance was rated on a scale of one to five based on the number observed and the area covered by the colony within the sixteenth section.

For each Red-talled Hawk territory, the sixteenth sections that most closely conformed to the actual territory boundaries were used to derive habitat measures. The variables selected pertain to suitability for Red-tailed Hawk foraging, prey presence and abundance, nest sites, and human presence.

Variables affecting sultability of a territory for foraging include hunting perches, topography, and vegetative structure. A number of variables involving density and dispersion of hunting perches and topography were derived to test the importance of these features. Perches were defined as junipers greater than $2 m$ tall, utility poles, and poplars. Topography was assessed using both the average and percentage of a territory (sixteenth sections) with greater than 61m (ten contour lines) elevational difference. The measures involving dispersion were derived as follows. A sixteenth section was considered adequate for efficlent foraging under several conditions involving minimum perch densities. The minimum densities include one, three, five, seven, and ten perches. Other measures, adding the presence of cliffs and elevational differences, were developed. For example, a sixteenth 
section was considered huntable if it contained either the required number of perches or either a cliff or an elevational difference equal to or greater than $61 \mathrm{~m}$.

Vegetative structure was also tested with respect to Red-tailed Hawk territory productivity. A high density of shrubs or trees could potentially interfere with the observation and capture of prey. The percentage of a territory that was dominated by shrub or tree species was tested against territory productivity.

Several variables regarding prey presence and abundance were tested. These include the number of sixteenth sections with elther Belding's or Townsend's ground squirrel colonies or both, the relative abundance of ground squirrels, the amount of surface water, and the abundance of wheat.

The avallability of nest sites was also tested against territory productivity. Junipers greater than $5 \mathrm{~m}$ tall, poplars, and oliffs were considered potential nest sites. Utility poles, though used as nest sites, were not considered as they are inferior to other nest sites and produce significantly less young (Janes, unpublished data). To test the effect of continual human presence on Red-ta1led Hawk productivity, territories were separated into two classes, those with inhabited dwellings and those without.

The statistical tests used with respect to the above included both simple linear regression and step-wise multiple linear regression. To test the relationship involving human presence, the t-test was used. Only the 22 territorles with three or more years of productivity data were used in the analyses. All figures in percentage form were arcsine 
converted.

Interpair conpetition anong Red-tailed Hawks was tested on the basis of territory size. Territory size was determined by cutting and weighing territory representations traced from the territory maps. The method of determining territory boundarles is described above. These results were then tested against temitory productivity by sinple linear regression.

The effects of interspecies competition were also tested. Upon determination that Red-tailed Hawks and Swainson's Hawks were Interspecifically territorial, Red-talled Hawk territories were divided into two groups: those with contended boundaries and those with none. Differences in the territory productivity means for each group were then tested by the t-test. 
CHAPTER III

\section{RESULTS}

The major portion or all of 31 Red-talled Hawk territories existed on the study area. The rate of occupancy for these territories was 96\% ( $n=152)$. Other diurnal raptors occupying the study area included Swainson's Hawks (16 pairs), Golden Eagles (Aquila chrysaetos, 2 pairs). Prairle Falcons (Falco mexicanus, 3 pairs), and American Kestrels (Falco sparverius, approximately 35 pairs).

Red-talled Hawks in the valley are migratory. A few birds (less than $10 \%$ of the breeding population) winter in the valley, hut it is unknown whether these are a part of the breeding forulation. Band returns from Oregon Red-talled Hawks have come from as far away as central Mexico (USDI, personal communication). The hawks arrive on the area over a short period of time usually during the second week in March. Almost immediately upon arrival they establish territories. Territory boundaries change very little from year to year with few exceptions and are maintained by the pairs throughout their stay on the area. Judging from the many individuals recognized by their distinctive plunage, there is very falthful return to previously held territories. Territories are strongly defended. Defense depends on many factors including weather, time of day, behavior of the intruder, and behavior and condition of the proprietor. Hunting areas, perches, and the nest vioinity are most actively defended. 
The period of egg-laying and the initiation of incubation occur during the last week of March and the first few days of April. The average date for the initiation of incubation for the five years with adequate data is April 1. The average for each year has fallen with in two days of this date. Extreme dates for individual pairs are March 17 and April 16.

Summaries of both territory and annual productivity and its component parts (Tables I and II) are based on data adjusted for human disturbance. Human influence had a relatively minor effect upon Redtailed Hawk productivity. Only five cases of disturbance were noted out of 114 nesting attempts (4\%) involving three pairs. Three cases apparently involved people taking young; the other two involving workers pushing nests with eggs off utility poles. No cases of predation were observed on any nest. No cases of nest desertion could be attributed to investigator disturbance.

Belding's ground squirrels comprised the greatest portion of the food taken both in terms of individuals and biomass (Table III). The importance of Belding's and Townsend's ground squirrels is probably underestimated as most of the food data originated from pairs with belok average numbers of these species in their territorles. Of the 31 pairs of Red-talled Hawks, all but one had either a Belding's or a Townsend's ground squirrel colony on their territory. Twenty-s1x (84\%) have Belding's ground squirrels, and ten pairs (34\%) have Townsend's ground squirrels. Prey species of secondary importance include mountain cottontails (Sylvilagus nuttaili1) and northern pocket gophers (Thomomys talpoides). 
SUMMARY OF RED-TAILED HAWK TERRITORY PRODUCTIVITY MISSING FIGURES ARE YEARS WTTHOUT DATA

PARENTHESES INDICATE THAT THE

TERRITORY WAS UNOCCUPIED

\begin{tabular}{|c|c|c|c|c|c|c|c|c|c|}
\hline Pair & 1973 & 1974 & 1975 & 1976 & 1977 & 1978 & 1979 & & justed \\
\hline \multicolumn{4}{|l|}{ Highlander } & & & 0 & & .00 & .67 \\
\hline Hasting & 2 & 2 & 2 & 2 & 2 & 2 & 2 & 2.00 & 2.00 \\
\hline $\begin{array}{l}\text { PPL } \\
\text { Weasel }\end{array}$ & & & 0 & & 2 & 1 & $\begin{array}{l}2 \\
3\end{array}$ & $\begin{array}{l}1.25 \\
3.00\end{array}$ & $\begin{array}{l}1.57 \\
3.02\end{array}$ \\
\hline Four H1ls & & & & 0 & 2 & 0 & & .67 & .99 \\
\hline $\begin{array}{l}\text { Grub Hollow } \\
\text { Scrag }\end{array}$ & 0 & 0 & 0 & (0) & 0 & 2 & & .33 & .29 \\
\hline Scrag & & & 0 & & & & & .00 & .77 \\
\hline Armstrong & * & $2^{*}$ & 0 & 0 & 0 & 0 & 0 & .33 & .50 \\
\hline $\begin{array}{l}\text { Antelope } \\
\text { Windsock }\end{array}$ & 4 & 4* & 3 & * & $\begin{array}{l}2 \\
3\end{array}$ & * & 1 & $\begin{array}{l}2.80 \\
3.00\end{array}$ & $\begin{array}{l}2.55 \\
2.85\end{array}$ \\
\hline Kaber & & & & 2 & & 0 & 3 & $1.6 ?$ & 2.05 \\
\hline $\operatorname{Max}$ & & & & 3 & 2 & 0 & 2 & 1.75 & 1.98 \\
\hline Watershed & 2 & 0 & 0 & $(0)$ & 2 & (0) & 0 & .57 & .57 \\
\hline Savannah & & & & & & 0 & 0 & .00 & .34 \\
\hline Boar Coon & & & & & & & 2 & 2.00 & 2.02 \\
\hline Lone Poplar & & & & & & 0 & 0 & .00 & .34 \\
\hline Ashburn & 3 & 3 & & 0 & $(0)$ & 0 & 2 & 1.33 & 1.21 \\
\hline Horse Harness & & & 0 & 0 & 2 & 2 & 2 & 1.20 & 1.55 \\
\hline Muddy Crossroads & & 2 & 0 & 2 & 2 & 3 & 3 & 2.00 & 2.17 \\
\hline Cold Camp Creek & & & 0 & 2 & 3 & 0 & 3 & 1.60 & 1.89 \\
\hline Lazuli & & & 0 & & 0 & 0 & 0 & .00 & .32 \\
\hline Homestead & & & 0 & & & 0 & 0 & .00 & .48 \\
\hline Van Gullder & & & & & 2 & 0 & 0 & $.6 ?$ & .84 \\
\hline Badger B1n & & 2 & & 0 & 2 & 3 & 3 & 2.00 & 2.04 \\
\hline Eagle Valley Gate & & & 1 & 0 & & & & .50 & 1.10 \\
\hline Pine Ridge & & & & & 1 & (0) & $(0)$ & .33 & .50 \\
\hline Kal1 & & & & & & 0 & 0 & .00 & .33 \\
\hline King Canyon & & & & & & 2 & 2 & 2.00 & 2.34 \\
\hline Foreman & 3 & 3 & & 3 & 0 & 0 & 0 & 1.50 & 1.50 \\
\hline Borthwick & 3 & 3 & 0 & 0 & 2 & 2 & 2 & 1.71 & 1.71 \\
\hline Snowst orm & 2 & & 3 & & & & 2 & 2.33 & 2.26 \\
\hline
\end{tabular}

$\begin{array}{lllllllll}\text { Young/territory } & 2.38 & 2.10 & .60 & .93 & 1.53 & .71 & 1.36 & 1.37\end{array}$

$\begin{array}{llllllll}\text { a. } & 8 & 10 & 15 & 15 & 19 & 21 & 25\end{array}$

* Figures were compensated for human disturbance (see text). 


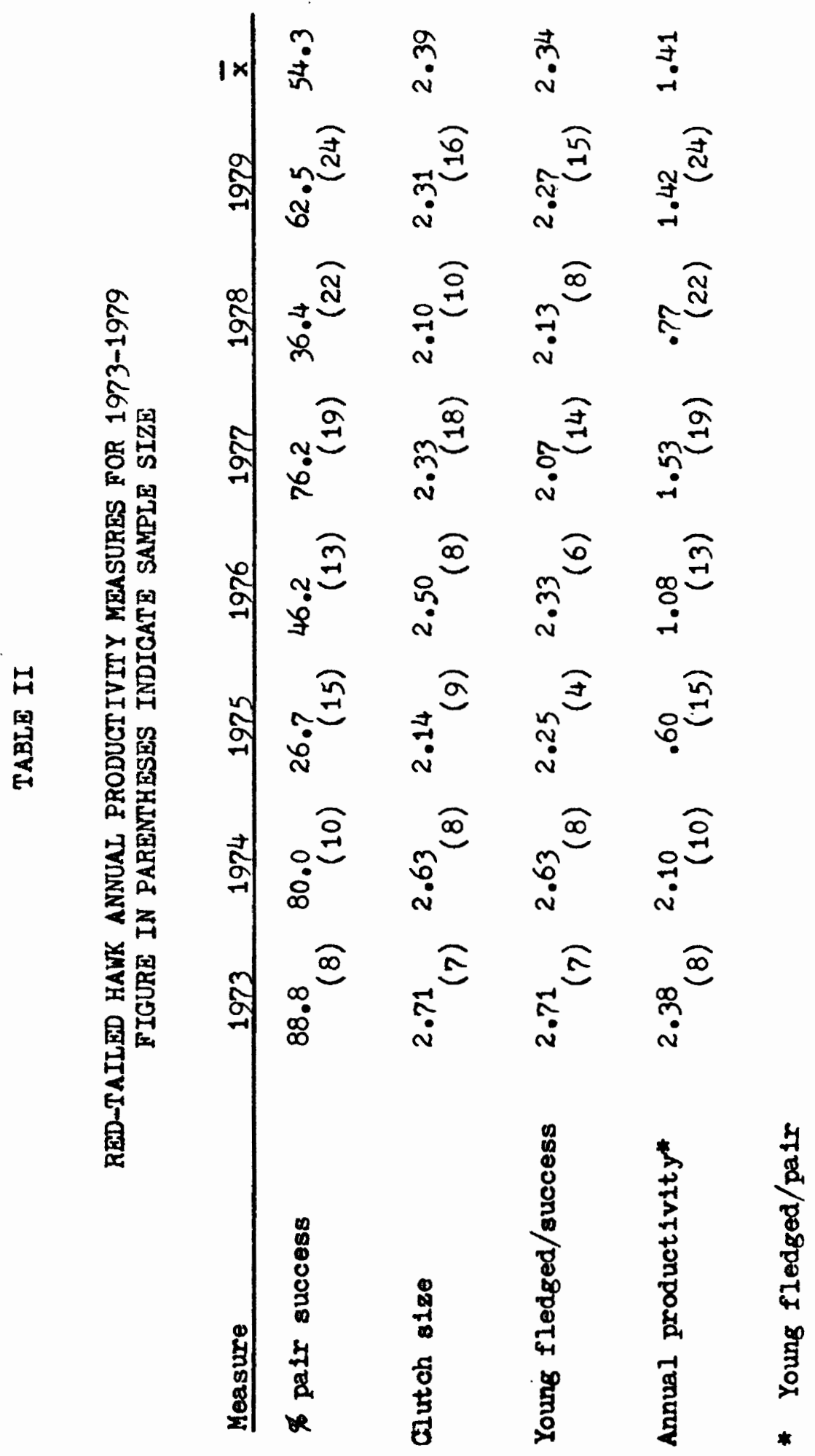


RED-TAILED HAWK FOOD HABITS DEMERMINED FROM PREY REMAINS FOUND AT THE NEST SITE AND FREY OBSRRVED CAPTURED

\begin{tabular}{|c|c|c|c|c|c|}
\hline pecies & Indv. & Ind $v$. & $\begin{array}{c}\text { Indv. } \\
\text { Blomass } \\
(\varepsilon)\end{array}$ & $\begin{array}{c}\text { Total } \\
\text { Biomass } \\
(\mathrm{s})\end{array}$ & $\begin{array}{c}\% \\
\text { Bionass }\end{array}$ \\
\hline
\end{tabular}

Spermoph1lus beldingi

Belding 's ground squirrel

$\begin{array}{lllll}15 & 34.1 & 243^{1} & 3645 & 48.9\end{array}$

Spermophilus townsend if

Townsend's ground squirrel

Syluilagus nuttalli1 nountain cottontail

Thomonys talpoides northern pocket gopher

Microtus montanus montane vole

Peromyscus maniculatus deer mouse

$\begin{array}{lllll}3 & 6.8 & 166^{2} & 498 & 6.7\end{array}$

$\begin{array}{lllll}3 & 6.8 & 433^{2} & 1299 & 17.4\end{array}$

$\begin{array}{lllll}7 & 15.9 & 70^{3} & 490 & 6.6\end{array}$

Total Mammal

$3 \quad 6.8 \quad 30^{2}$

$90 \quad 1.2$

$\begin{array}{lllll}2 & 4.5 & 22^{3} & 44 & .6\end{array}$

$33 \quad 75.0$

6066

81.3

Coluber constrictor common racer

unidentified snake

Total Reptile

Plca pica

black-billed magpie

Sturnella neglecta

western meadowlark

Themophila alpestris

horned lark

unidentified bird

Total Bird

Total

1 Portland State University collection

2 USDI (1979)

3 This study $\begin{array}{lllll}2 & 4.5 & 77^{2} & 154 & 2.1\end{array}$

$\begin{array}{lllll}4 & 9.1 & 207^{2} & 828 & 11.1\end{array}$

$\begin{array}{llll}6 & 13.6 & 982 & 13.2\end{array}$

$\begin{array}{lllll}1 & 2.3 & 170^{2} & 170 & 2.3\end{array}$

$\begin{array}{lllll}1 & 2.3 & 96^{2} & 96 & 1.3\end{array}$

$\begin{array}{lllll}1 & 2.3 & 26^{2} & 26 & .3\end{array}$

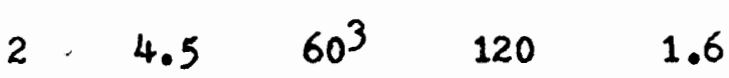

$\begin{array}{llll}5 & 11.4 & 412 & 5.5\end{array}$

$44 \begin{array}{lll}400.0 & 7460 \quad 100.0\end{array}$ 
Although percent pair success, clutch size, and young fledged per success were significantly correlated with annual productivity, percent pair success was the best predictor of annual productivity. Percent pair success alone contributed to $95 \%(p<.01)$ of the variability. Clutch size and young fledged per success accounted for $77 \%(p<.01)$ and $59 \%(p<.05)$ respectively of the variability in annual productivity. However, neither clutch size nor young fledged per success varied significantly from year to year.

No weather variables were found that significantly correlated With annual productivity (Table IV), but percent pair success was significantly correlated with January precipitation (Table V). However, the winter of 1978-1979, especially the month of January, was unusually severe. A January temperature $14.4 \mathrm{~g}$ below average is expected about once every 161 years $(p<.0062)$. Thus, it may be more instructive to look at the results from the six previous years, omitting 1979 in reference to January variables (Table VI). The results in this case show significant correlations between annual productivity and both 174 degree date and January average temperature. Percent pair success is significantly correlated with four January related variablesı 174 degree date, January average temperature, January precipitation, and January through April precipitation.

All weather variables significantly correlated with annual productivity or percent pair success involve the period of the onset of rapid vegetative growth of the year in question. No correlations were found with the previous growing season, previous summer weather, or weather potentially affecting Red-talled Hawk incubation and egg-lay- 
TABLE IV

SIMPLE IINEAR REGRESSION ANALYSES OF RED-TAILED HAWK ANNUAL PRODUCTIVITY TO WEATHER CORRELATIONS

FOR 1973-1979

Variable

Direct Effects

March precipitation

March average temperature

April precipitation

April average maximun temperature

Previous Growing Season

January precipltation

January average temperature

January-Apr 11 precipitation

January-April average temperature

April-Kay precipitation

April-May average temperature

174 degree date

Previous Summer

June-July precipitation

July precipitation

July average temperature

Immediate Grouing Season

September-January precipitation

Sept ember-April precipitation

January precipitation.

January-April precipitation

January-April average temperature

174 degree date $r^{2}$

Slope

$.004 \quad-.092$

$.008 \quad .021$

$.289 \quad-.472$

$.279 \quad .073$

.330

.567

.028

.060

.035

.101

$.008 \quad .053$

$.067 \quad-.165$

.217

.166

.065

.021

$.073 \quad .231$

$.016 \quad-.157$

$.321 \quad .320$

$.000 \quad .000$

$.102 \quad-1.54$

$.502 \quad-.814$

$.350 \quad .217$

$.000 \quad .000$

$.279 \quad .028$

* $p<.05$

$* * p<.01$ 
TABLE V

SIMPLE IINEAR REXRESSION ANALYSES OF RED-TAILED HAWK PERCENT PAIR SUCGESS TO WEATHER CORREHAT IONS FOR 1973-1979. Y-IMTBRCFPT PROVIDED IF A CORRELATION IS SIGNIFICANT

Varlable. $r^{2}$ Slope Y-intercept

Direct Iffects

March precipitation

March average temperature

April precipitation

April average maximum temperature

Previous Growing Season

January precipitation

January average temperature

January-April precipitation

January-April average temperature

Apri1-May precipitation

April-May average temperature

174 degree date

Previous Sunmer

June-July precipitation

July precipitation

July average temperature

Immediate Growing Season

September-January precipitation

Sept ember-April precipitation

$\begin{array}{lr}.024 & -5.81 \\ .006 & .500 \\ .368 & -14.2 \\ .480 & 2.55\end{array}$

.383

16.4

$.093 \quad 1.70$

$.085 \quad 3.19$

$.015 \quad 1.99$

.050

.195

$-3.84$

.026

4.21

.347

$.076 \quad 6.32$

$.018 \quad-4.54$

.253

7.60

$.018 \quad-.806$

$.029 \quad-.031$

$.644 * \quad-24.7$

$.155-1.01$

$.472 \quad-6.73$

$.008 \quad .723$

$.335 \quad .811$
January precipitation

January average temperature

January-April precipitation

January-April average temperature

174 degree date

67.1

* $p<.05$

** $p<.01$ 


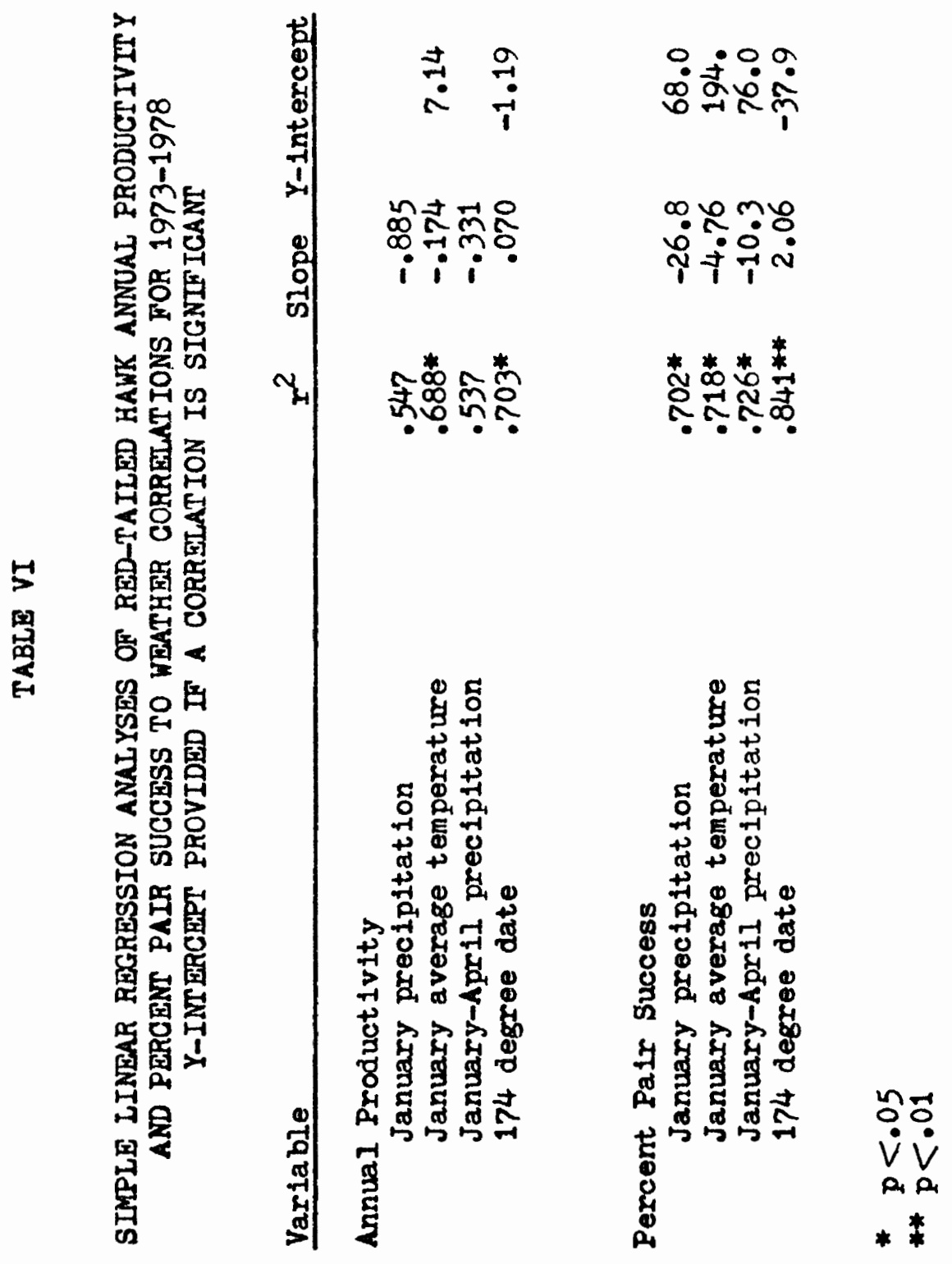


ing. No combination of variables significantly added to the amount of varlation answered by the above variables alone.

Results of habitat correlates to territory productivity tests are presented in Table VII except those pertaining to human presence. Only two parameters were found to be significant in the absence of others. These, include percentage of a territory with one or more perches per sixteenth section and percentage of a territory with one or more perches or a cliff per sixteenth section. Other measures of perch dispersion incorporating greater perch densities were insignificant. However, in combination with relative ground squirrel abundance all perch dispersion measures were significant (Table VIII). Relative ground squirrel abundance was not signiflcant by itself. The best predictor of territory productivity was a combination of percentage of a territory with one or more perches or a cliff per sixteenth section and relative ground squirrel abundance. Other parameters did not contribute significantly to these results. Territory size also had no observable effect upon productivity.

Territory productivity was positively and significantly correlated to the presence of inhabited dwellings. Pairs with inhabited dwellings fledged on the average 1.75 young per pair while those without inhabited dwellings fledged only 1.11 young per pair $(p<.01)$.

Red-ta1led Hawks and Swainson's Hawks were strongly interspec1flcally territorlal. Swainson's Hawks arrive on the study area between April 4 and 15. The range of individual plumage variation between Swainson's Hawks in the Antelope area and their behavior permit identification of Individuals with some confidence, and Swainson's Hawks 


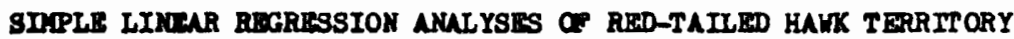
PRODUCIIVIYY TO HABIINT CORREATIONS. Y-IMTERCEPI PROVIDED I A coRaticion IS SIGNIPICAM

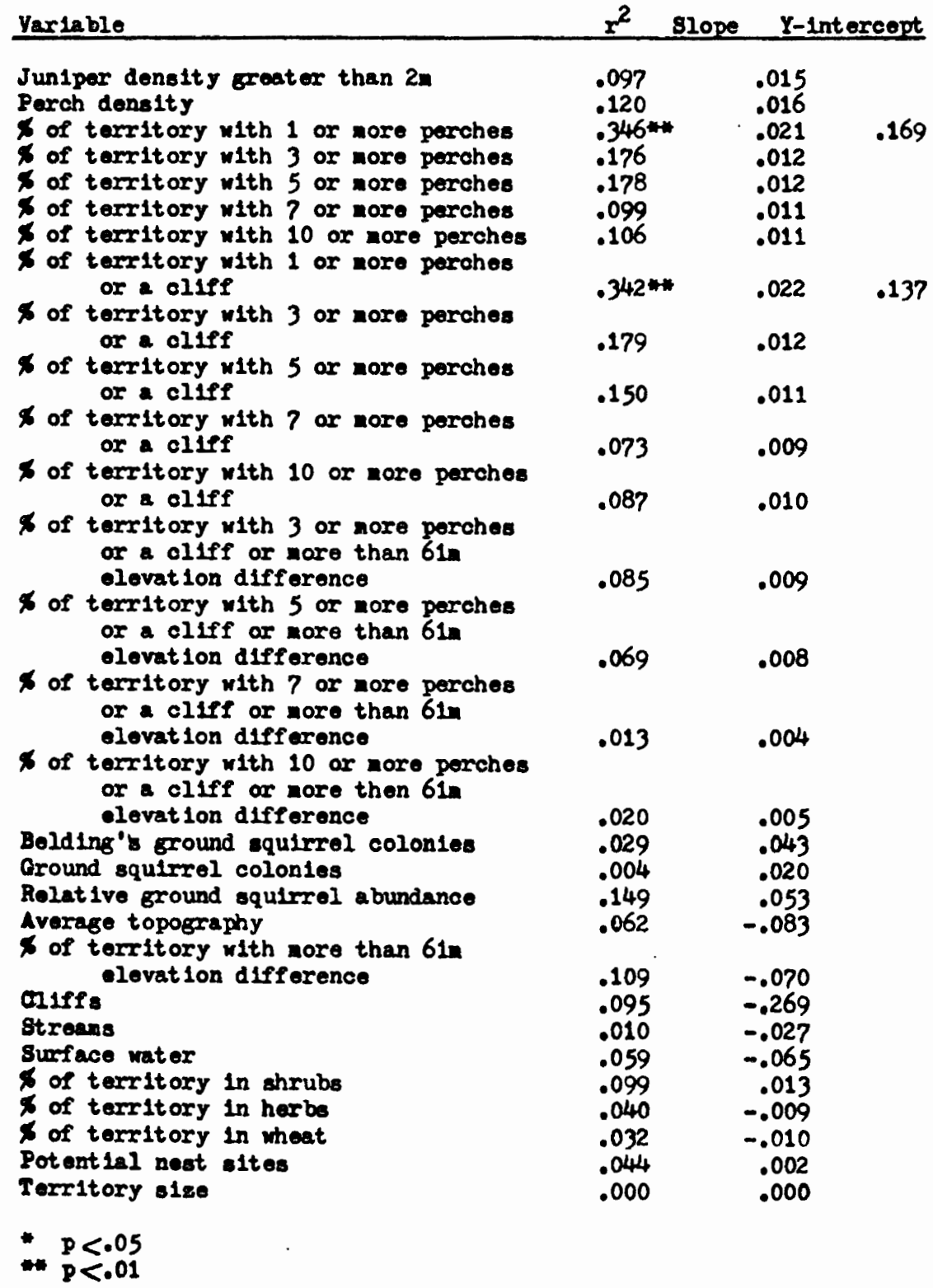


STIE-WISE MUITIPLE IINEAR REGRESSION AKLLYSES OF RED-TAILED HAWK TEARTIORY PRODUCTIVITY TO HABITAT REMINTIONSHIPS.' THE SLOPES ARE FOR VARIABLES IN THE EQUATION ATTER THE IAST SIGNIFICANT VARIABLE HAS BERN EMTERED

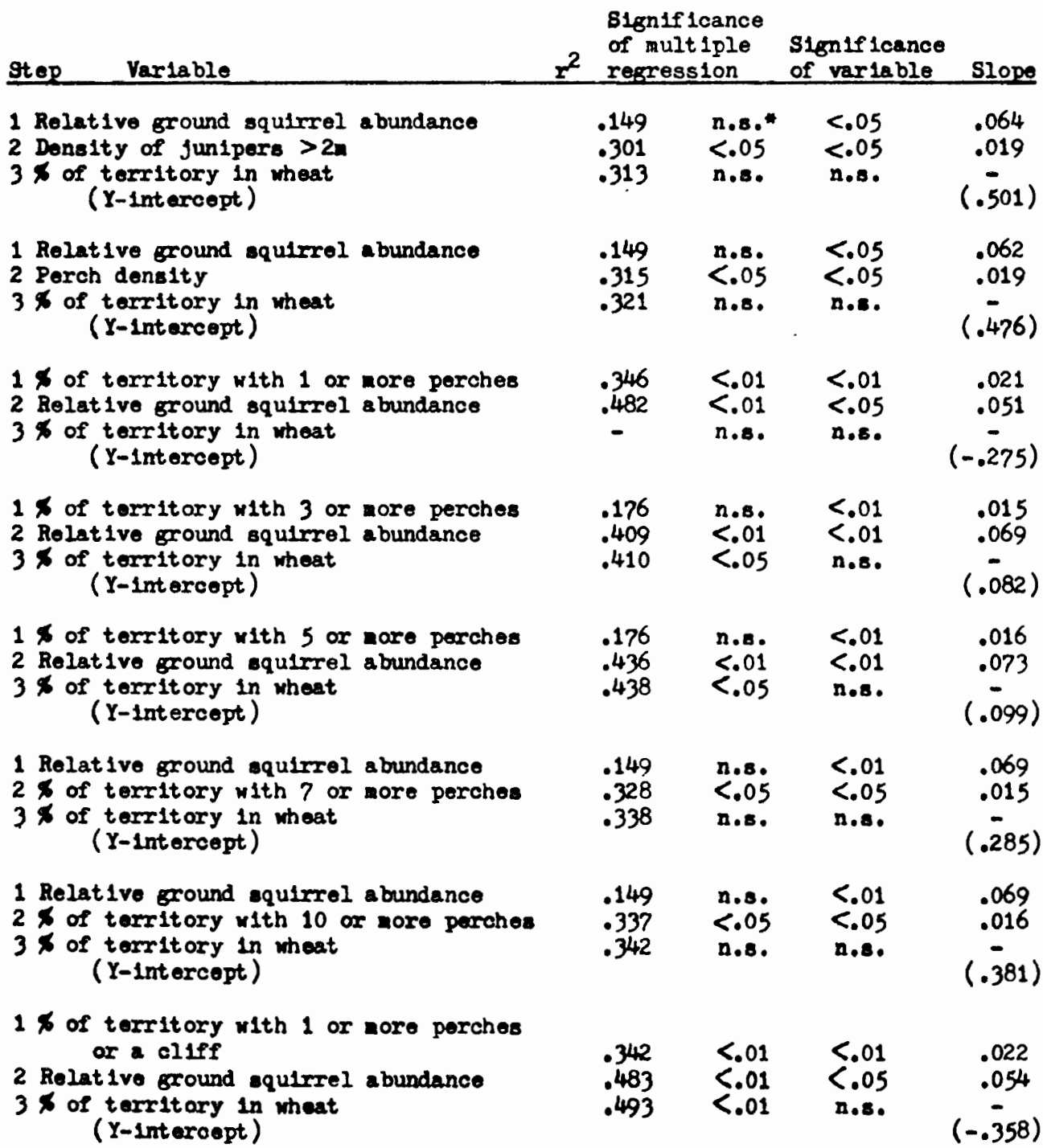


TABLE VIII (Cont.)

\begin{tabular}{|c|c|c|c|c|}
\hline \multirow{2}{*}{$\begin{array}{l}\text { Step Variable } \\
1 \% \text { of territory with } 3 \text { or more perches } \\
\text { or a ollff } \\
2 \text { Rolat ive ground squirel abundance } \\
3 \% \text { of territory in wheat } \\
\text { ( } Y \text {-intercept) }\end{array}$} & $\mathbf{r}^{2}$ & $\begin{array}{l}\text { signif loance } \\
\text { of nult 1plo } \\
\text { regression }\end{array}$ & $\begin{array}{l}\text { Significance } \\
\text { of variable }\end{array}$ & Slope \\
\hline & $\begin{array}{l}.179 \\
.429 \\
-\end{array}$ & $\begin{array}{l}\text { n.8. } \\
<.01 \\
\text { n. }\end{array}$ & $\begin{array}{l}<.01 \\
<.01 \\
\text { n.8. }\end{array}$ & $\begin{array}{c}.016 \\
.071 \\
(003)\end{array}$ \\
\hline $\begin{array}{l}1 \% \text { of territory with } 5 \text { or more perches } \\
\text { or a cliff } \\
2 \text { Relat Ive ground squirrel abundance } \\
3 \text { of territory in wheat } \\
\text { (Y-intercept) }\end{array}$ & $\begin{array}{l}.150 \\
.436 \\
.437\end{array}$ & $\begin{array}{l}\text { n.8. } \\
<.01 \\
<.05\end{array}$ & $\begin{array}{l}<.01 \\
<.01 \\
n .6 .\end{array}$ & $\begin{array}{c}.016 \\
.078 \\
- \\
(.013)\end{array}$ \\
\hline $\begin{array}{l}1 \text { Relative ground squirrel abundance } \\
2 x \text { of territory with } 7 \text { or more perches } \\
\text { or a cliff } \\
3 \times \text { of territory in wheat } \\
\text { (Y-intercept) }\end{array}$ & $\begin{array}{r}.149 \\
.319 \\
.330\end{array}$ & $\begin{array}{l}\text { n.8. } \\
<.05 \\
\text { n.8. }\end{array}$ & $\begin{array}{l}<.01 \\
<.05 \\
\text { n.8. }\end{array}$ & $\begin{array}{c}.073 \\
.015 \\
(.231)\end{array}$ \\
\hline $\begin{array}{l}1 \text { Relative ground squirrel abundance } \\
2 \% \text { of torritory with } 10 \text { or more perches } \\
\text { or a oliff } \\
3 \% \text { of territory in wheat } \\
\text { (Y-Intercept) }\end{array}$ & $\begin{array}{l}.149 \\
.337 \\
.342\end{array}$ & $\begin{array}{l}\text { n.e. } \\
<.05 \\
\text { n.s. }\end{array}$ & $\begin{array}{l}<.01 \\
<.05 \\
\text { n.8. }\end{array}$ & $\begin{array}{l}.073 \\
.016 \\
(.309)\end{array}$ \\
\hline $\begin{array}{l}1 \text { Relat ive ground squirrel abundance } \\
2 \% \text { of territory with } 3 \text { or more perches } \\
\text { or a cliff or more than } 61 \mathrm{~h} \\
\text { olevation difference } \\
3 \times \text { of territory in wheat } \\
\text { (Y-intercept) }\end{array}$ & $\begin{array}{l}.423 \\
.431\end{array}$ & $\begin{array}{l}<.01 \\
<.05\end{array}$ & $\begin{array}{l}<.01 \\
\text { n.8. }\end{array}$ & $\begin{array}{c}.090 \\
.018 \\
(-.508)\end{array}$ \\
\hline $\begin{array}{l}1 \text { Relative ground squirrel abundance } \\
2 \times \text { of territory with } 5 \text { or nore perahes } \\
\text { or a cliff or more than } 61 \text { a } \\
\text { elevation differenoe } \\
3 \times \text { of territiory in wheat } \\
\text { ( } Y \text { - intercept) }\end{array}$ & $\begin{array}{l}.423 \\
.426\end{array}$ & $\begin{array}{l}<.01 \\
<.05\end{array}$ & $\begin{array}{l}<.01 \\
\text { n.8. }\end{array}$ & $\begin{array}{c}.095 \\
.019 \\
(-.448)\end{array}$ \\
\hline 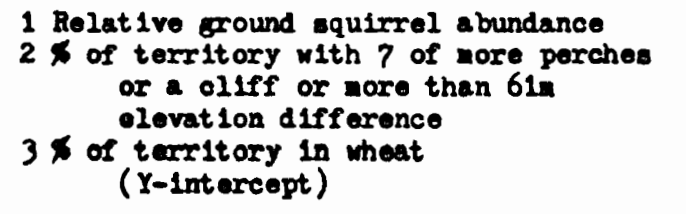 & $\begin{array}{l}.294 \\
.299\end{array}$ & $\begin{array}{l}<.05 \\
\text { n.8. }\end{array}$ & $\begin{array}{l}<.05 \\
\text { n.8. }\end{array}$ & $\stackrel{.015}{(-.112)}$ \\
\hline 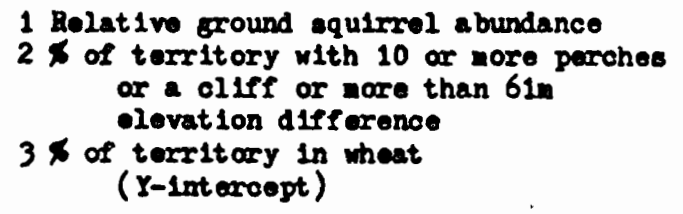 & $\begin{array}{l}.311 \\
.316\end{array}$ & $\begin{array}{l}<.05 \\
\text { n.e. }\end{array}$ & $\begin{array}{l}<.05 \\
\text { n.e. }\end{array}$ & $\begin{array}{c}.015 \\
(-.047)\end{array}$ \\
\hline
\end{tabular}


appear to be as faithful to territories as Red-tailed Hawks. Usually within 24 hours of their arrival, Swainson's Hawks have established territortal boundaries conforming quite closely to those of the prevlous year. If adjacent Red-tailed Hawks have incorporated what becomes Swainson's Hawk territory into their own, the resulting confrontation can be impressive. The aerial combat between the two pairs can be very aggressive and last almost the entire first day. The males are Involved in most of the aggression, and the female Red-talled Hawk, which is normally incubating, participates little. By the second day the contesting of territorial boundaries drops off sharply though the resulting territorial boundaries are defended upon intrusion throughout the breeding season. Though Red-talled Hawks may lose territory to Swalnson's Hawks, this occurs only at the periphery of the Redtailed Hawk's range, and the resulting boundaries look very similar to those of the previous year. No significant difference in productivity was found between Red-tailed Hawk pairs contending with Swainson's Hawks and those that did not. 
GHAPTER IV

\section{DISCUSSION}

The principal factor determining annual productivity is the percentage of pairs that are able to successfully fledge young. Ne1ther clutch size nor survival of nestilngs appear to be significant. All significant correlations between percent pair success and various weather parameters involve January of the immediate year. If some event in January is responsible for percent pair success, it rules out direct effects upon the Red-talied Hawk since they winter to the south. This suggests that the significant factor has something to do with the onset of the immediate growing season, most $11 \mathrm{kely}$ the availability of prey.

The emergence of the principal prey, the Belding's ground squirrel, from hibernation varies from year to year (Costain 1977; Morton and Sherman 1978; Turner 1972). In the Sierra's of California emergence has been observed to vary as much as six weeks (Morton and Sherman 1978). This is at least. loosely correlated with weather and more directly related to the appearance of sufflcient forage (Costain 1977; Mort on and Sherman 1978, Turner 1972). Belding's ground squirrels in Oregon have been observed to emerge anytime from the thind week in January to April (Costain 1977) and possibly even June (Turner 1972) depending on the location and elevation. Antelope is near the lower elevation range of the Belding's ground squirrel, and the squirrels emerge quite early. Backdat ing from the omergence of young and from 
observations of landowners, the Antelope populations at least occaslonally energe as early as late January and as late as the end of February.

The reproductive cycle in the Belding's ground squirrel is timed from the point of emergence from hibernation (Turner 1972). Therefore, In a year where the beginning of rapid vegetative growth begins earlier, the Belding's ground squirrel would be expected to emerge earlier. By emerging earlier, this would advance their reproductive cycle.

The question now becomes one of explaining what conditions lead to the beginning of rapld vegetative growth. The principal forage for Belding's ground squirrels is succulent vegetation (Costain 1977, Tur- + ner 1972). In the Antelope area this is most commonly winter annuals, primarily cheatgrass, or the perennial alfalfa. Winter annuals in general and cheatgrass in particular germinate with the beginning of the fall rains in September and October (Harr1s 1967). Dhring the fall most of the growth is directed to the developing root system (Harris 1967). With the onset of cold weather, growth slows (Harris 1967). Warming late in the winter and early spring triggers rapld vegetative growth (Harris 1967). Cheatgrass is also sensitive to precipitation, and growth is limited by dry, cold spring weather (Harris 1967). In the Antelope area the beginning of rapid vegetative growth begins in late January or February. Alfalfa, too, begins vegetative growth with the onset of warmer weather. Therefore, a cold, dry January would be expected to delay the emergence of Belding's ground squirrels. This also helps explain why 174 degree date is more closely related to Red-tailed Hawk productivity than January average temperature. Plants 
presumably only grow appreclably when the temperature is above freezing. In this respect January average temperature is not the best measure of growing conditions. A day averaging $0^{\circ} \mathrm{F}$ and one of $20 \mathrm{~F}$ may be the same to the plants in terms of growth. Also, the period of January does not necessarily emcompass the entire period of importance. To relate this to Red-tailed Hawk productivity, it is necessary to examine their reproductive chronology and compare it to that of the Belding's ground squirrel (Figure 1). The date of the initiation of incubation does not appear to vary significantly. Therefore, the relative timing of breeding between Red-tailed Hawks and Belding's ground squirrels varies from year to year apparently in accordance with January and early February weather.

The period of greatest Belding's ground squirrel abundance and vulnerability to avian predators is during the emergence and dispersal of the numerous and inexperienced young. With a cold, dry spring and a delayed reproductive cycle, the period of high abundance and vulnerability occurs in May. May is the beginning of the period of the greatest food need in Red-tailed Hawks in any year. Young hatch about the first of May, and between the third week and fledging energetic demands upon the parents are greatest (Olendorff 1974). In this case the peaks of Belding's ground squirrel abundance and vulnerability coincides closely with the needs of the Red-tailed Hawk. These are also years with high percent pair success and as a result high annual productivity.

In a year where the 174 degree date is early and above normal precipitation has occurred, the ground squirrel season is expected to 
告

\begin{tabular}{l}
0 \\
0 \\
0 \\
0 \\
0 \\
0 \\
0 \\
0 \\
4 \\
4 \\
\hline
\end{tabular}

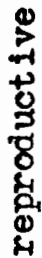

क्ष

ษิ

כू

어

롱

요

क्ष

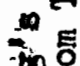

कैष

兽兽

क्ष

空

要

'马

至品

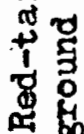

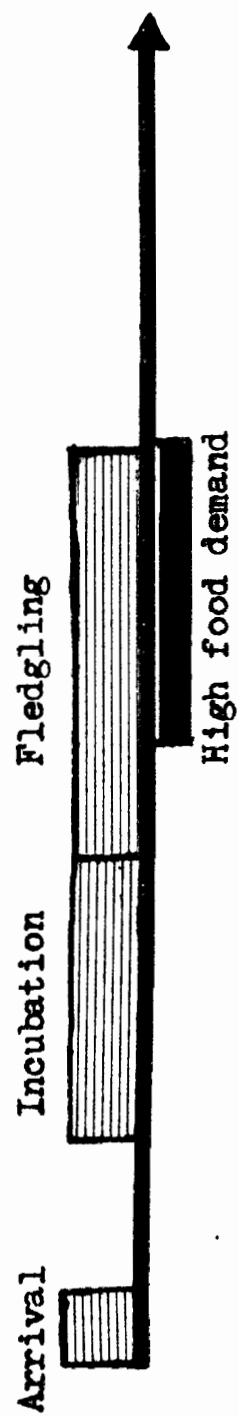

क्ष

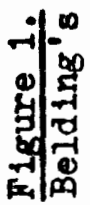

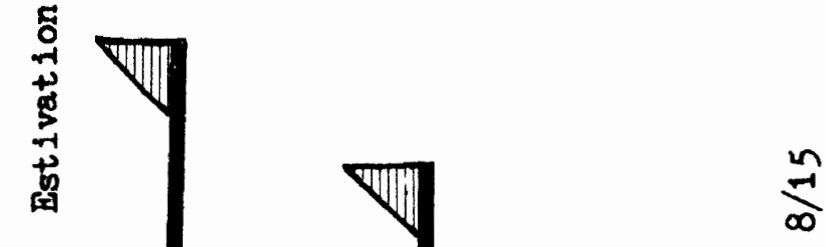

$\stackrel{\infty}{\curvearrowright}$

$\frac{O}{N}$

$\stackrel{m}{n}$

$\stackrel{n}{N}$

$\stackrel{\infty}{\stackrel{N}{N}}$

$\stackrel{\infty}{N}$.

兵

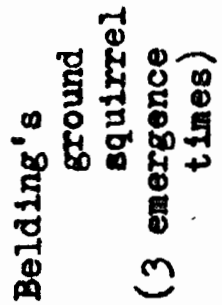

$\infty$
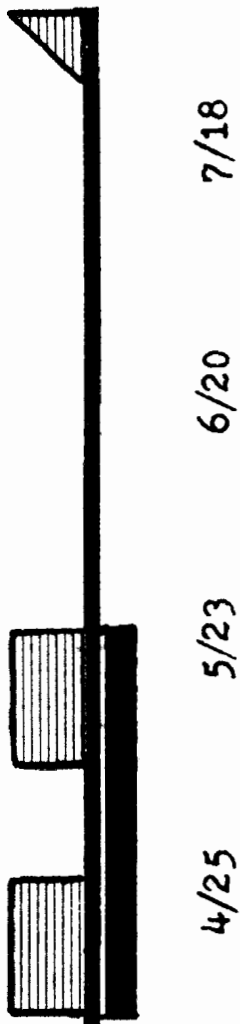

n
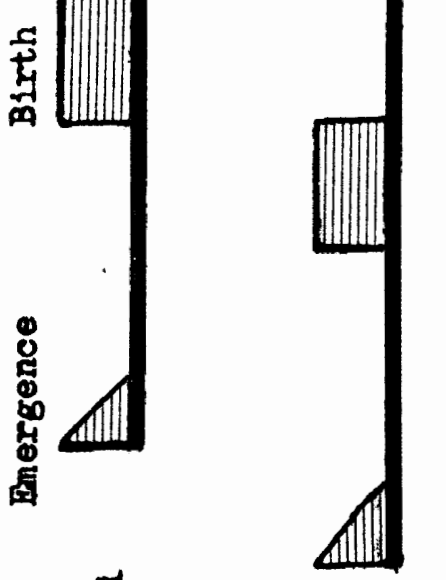

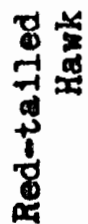
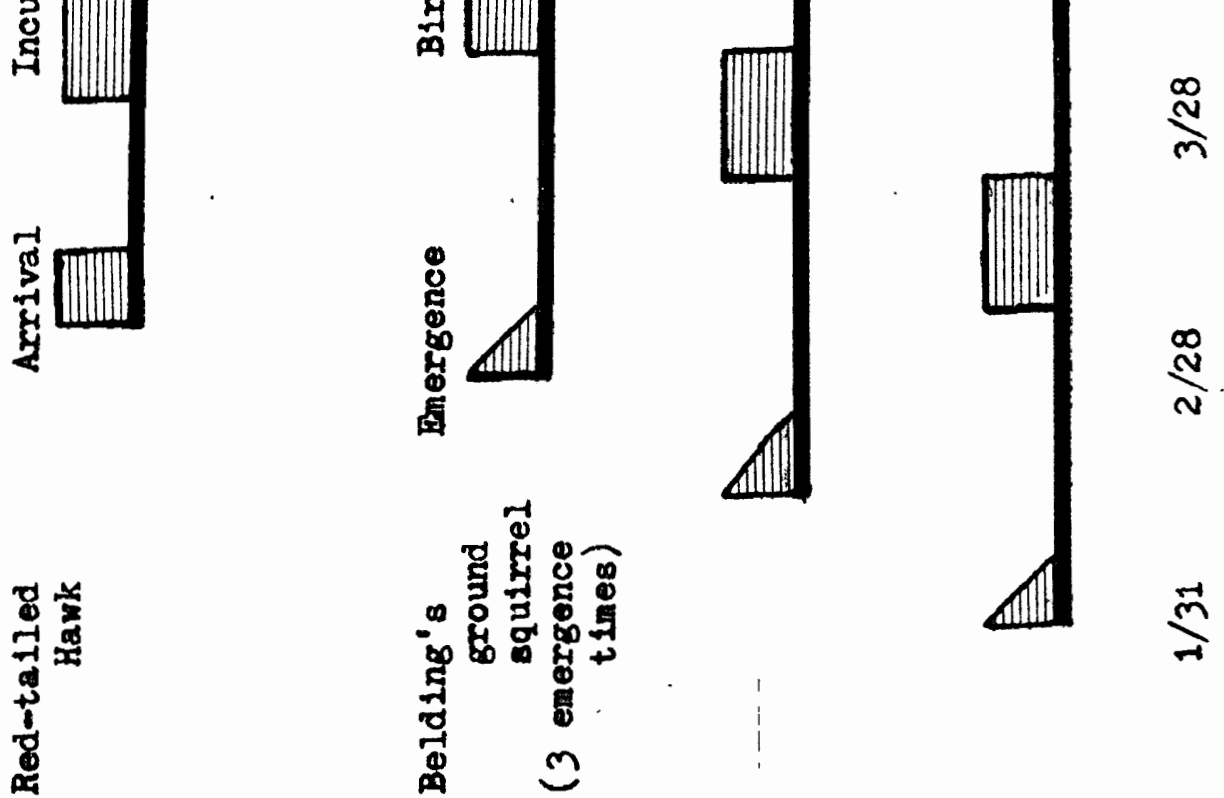
be advanced. In this case the perlod of peak prey abundance and vulnerabllity would occur in April, well prior to the increasing food demand of Red-tailed Hawk young (mid-May). By the time Red-tailed Hawk prey needs increase, the dispersal of young Beling's ground squirrels is already well underway. These young are now somewhat experlenced and most have their own burrow (Turner 1972). As such they are no longer as susceptible to predation (Craighead and Craighead 1956). These are also years when Red-tailed Hawk pair success is below average.

The degree to which peak needs in the Red-tailed Hawk and peak avallability in the Belding's ground squirrel colncide appear to largely determine pair success. This has less to do with actual prey abundance than relative prey abundance. In fact, if emergence time is delayed significantly (normally benefitting Red-talled Hawks in terms of productivity), higher mortality has been found to occur in Belding's ground squirrels (Morton and Sherman 1978). This is caused by starvation through the depletion of stored fat reserves in the Belding's ground squirrels. If actual prey abundance was the principal factor determining Red-talled Hawk productivity, then one might expect the slope of the correlation to be reversed. Another polint suggesting the lack of importance of actual prey abundance stems from the lack of correlation between Red-tailed Hawk productivity and weather of the

- previous growing season. Costain (1977) suggested that Belding's ground squirrel productivity is related to spring weather. These results may shed some light on the studies of McInvaille and KeIth (1974) and USDI (1979) where Red-talled hawk productivity did not correlate well with 
ground squirrel numbers though they constituted a major source of prey. The year of 1979 was a year where a marked reduction in actual prey abundance probably had a significant impact upon Red-talled Hawk productivity. Part of the reduction in Belding's ground squirrel numbers may be attributed to an extremely cold January and, therefore, delayed onset of rapld vegetative growth and higher ground squirrel mortality. In addition, when the warm-up began in February, it occurred suddenly, and the accumulated snow melted rapldiy. There was extensive flooding of many of the Belding's ground squirrel colonies undoubtedly causing greater than normal mortality (Turner 1972). Both these events worked to create an unusual prey situation. In this case, the importance of actual prey abundance apparently had a much greater impact upon Red-tailed Hawk productivity than normal.

The same kind of effect that has been observed in Belding's ground squirrels regarding timing of emergence most $11 \mathrm{kely}$ holds for the Townsend's ground squirrel as well. The impact of this apparent situation is pronounced because ground squirrels bear a single litter annually which is synchronized by the timing of emergence. This is different from most other Red-talled Hawk prey species, notable lagomorphs and microtines (Smith and Murphy 1973; Craighead and Craighead 1956).

The effects of the timing of the onset of rapid vegetative growth may also affect other prey than ground squirrels. Pocket gophers are an important secondary prey source for Red-talled Hawks in the Antelope area. They, as the ground squirrels, bear a single litter a year though less symchronized (Turner et al., 1973). Spring warm-up is likely to affect pocket gophers by improving foraging conditions especially in 
the Antelope area where snow cover is rare, and the ground is more susceptible to sub-freezing weather.

In other prey, multi-littered prey specles such as lagomorphs and microtines may breed earlier in response to an advanced spring. By breeding earlier they may produce more litters and therefore more offspring. This potential increase would work counter to the pattern described above where delayed green-up benefits Red-tailed Hawk productivity. Lagomorphs and microtines are a comparatively minor prey source in this population.

Habitat also affects Red-tailed Hawk productivity. The combination of ground squirrel density and a minimum number of perches adequately dispersed throughout a territory appears to significantly affect a pair's reproductive success. Though Red-talled Hawks hunt while in flight particularly while soaring. perches are apparently more important for hunting. It was observed here and by Fitch et al. (1946) that adequate numbers of hunting perches are apparently "the most essential feature of a territory". This is also suggested by the lack of correlation between topography and a pair's reproductive performance. The presence of hills favors both declivity winds and thermals (Cone 1962).

Perch density alone was found to bo inadequate in predicting productivity. Several factors appear responsible. First, two territories with the same perch density could be quite different in suitability for hunting. A territory where the perches are poorly dispersed may leave large areas unavallable for perch hunting. Also more perches may be useful only up to a point even if they are highly dispersed. Too 
many perches in an area may impair hunting. Finally, ground squirrels are not normally assoclated with areas of high juniper density. JunIpers provide the vast majority of perches. Therefore, the dispersion of perches also needs to be considered.

The perch density that appears to be required assuning adequate dispersion seems surprisingly low. This was measured at one perch per sixteenth section, but this might be an over-estimate as lesser densities above zero were not measured. Unless the Red-tailed Hawk has an effective hunting radius of $227 \mathrm{~m}$ from these perches which average under $10 \mathrm{~m}$ tall, they are not hunting the entire territory from these perches. Using the replacement rate of 1.35 young per pair per year (Henny and Wight 1970) for the Red-talled Hawk and regression results here, roughly $83 \%$ of a territory needs adequate perches for a pair to be sustaining. The inimum percentage of a territory with adequate perches was $45 \%$.

Other measures that falled to be of Importance to habitat quality include surface water, wheat, and shrub density. Wheat in particular was expected to be negatively correlated with Red-tailed Hawk productivity. Annual plowing effectively oliminates prey including the Belding's ground squirrel (Turner 1972). However, the deep-solled areas preferred for the cultivation of wheat are also preferred by the Belding's ground squirrels. Though Belding's ground squirrels cannot exist on the plowed flelds, they do exist in some abundance in the remaining deep soll around the margins of the plowed fields. Shrub density was also expected to yleld a negative correlation to productivity. Cave (1968) and Southern (1970) have found that raptors prefer 
more open areas and that it does affect hunting. The explanation here does not appear to be so clear. Junipers, however, are positively correlated with shrub density $(x=.50)$.

The presence of people living on a Red-talled Hawk territory apparently disturbs the Red-tailed Hawks little. In fact, those territories with human habitations produced significantly more young. This is attributed to several factors. First, perches in the form of utility poles and poplars and certain other trees are associated with habitations. Second, houses are generally placed near water on level ground which is also the preferred habitat of the Belding's ground squirrel (Turner 1972). Olendorff and Stoddart (1974) found that raptors nesting in remote areas and on posted land produced significantly more young. This effect is presumably due to the lack of direct human disturbance, but this effect was not considered here.

Neither territory size nor interspecific competition was correlated with territory productivity. The size of a territory says little of its quality in a heterogeneous habitat. As a general observation, territories are larger for those pairs that either have to commute some distance from the nest to an important foraging area or those pairs that have a general lack of a concentrated prey source. Because of the traditional nature of territories, boundaries were observed to change only subtly over the years. Only one significant boundary change was observed in the 31 pairs during the course of the study. Competition in this population apparently takes the form of gaining entry into one of the territories by successfully filling an opening when it appears and not in changing territory size. Though population 
density can have an effect upon territory size, no significant population fluctuations were observed during the study. Density was found to affect productivity in the Kestrel (Cave 1968) and in the Tawny Owl (Southern 1970). In competition with the Swainson's Hawk, the Redtalled Hawk apparently is affected little. Those pairs regularly contesting territory each year with Swainson's Hawks fledge the same number of young as those that did not. 


\section{LIT GRATURE CITED}

Cave, A.J. 1968. The breeding of the Kestrel, Falco tinninculus I., in the reclaimed area Oostelijk Flevoland. Neth. J. Zool. 18, 313-407.

Cone, C.D. 1962. Thermal soaring of birds. Am. Sct. 50:180-209.

Costain, D.B. 1977. Dynamies of a population of Belding's ground squirrels in Oregon. M.S. thesis. Oregon State University, Corvallis.

Craighead, J.J. and F.C. Craighead. 1956. Hawks, Owls, and Hildlife. Stackpole Co. Harrisburg.

Fitch, H.S., F. Swenson, and D.F. Tillotson. 1946. Behavior and food habits of the Red-tailed Hawk. Condor 48:205-237.

Franklin, J.F. and C.T. Dyrness. 1973. Natural vegetation of Oregon and Washington. USDA Forest Service General Technical Report PNW-8.

Hagar, D.C. 1957. Nesting populations of Red-talled Hawks and Horned Owls in central New York state. Wilson Bull. 69:263-272.

Harris, G.A. 1967. Some competitive relationships between Agropyron spicatum and Bromus tectorum. Ecol. Monog. 37:89-111.

Henny, C.J. and H.M. Wight. 1972. Population ecology and environmental pollution, red-tailed and Cooper's hawks. Pp. 229-250 in Population ecology of migratory birdss a symposium. USDI Wildl. Res. Rep. 2.

Houston, C.S. 1975. Reproductive performance of Great Horned Owls in Saskatchewan. Bird-Banding 46:302-304.

Hussell, D.J.T. 1972. Factors influencing clutch-size in arctic passerines. Ecol. Monog. 42,317-364.

Klomp, H. 1970. The determination of clutch-size in birdss a review. Andea 58,1-124.

Lack, D. 1947. The significance of clutch-size. Parts I and II. Ibis $89,302-352$.

Lack, D. 1948. The significance of clutch-size. Part III. Ibis 90, 25-45. 
Iutt1ch, S.N., L.B. Keith, and J.D. Stephenson, 1971. Population dynamics of the Red-tailed Hawk (Buteo jamaicensis) at Rochester, Alberta. Auk 88:75-87.

Luttich, S.N., D.H. Rusch, E.C. Meslow, and L.B. Keith. 1970. Ecology of Red-tailed Hawk predation in Alberta. Ecology 51:190-203.

McInvaille, W.B. and L.B. Keith. 1974. Predator-prey relations and breeding biology of the Great Horned OwI and Red-tailed Hawk in central Alberta. Can. Field Nat. 88,1-20.

Mebs, T. 1964. Zur Biologie und Populationsdynamik des Mausebussards (Buteo buteo) (Unter besonderer Berucksichtigung der Abhangigkeit vom Massenwechsel der Feldmaus Microtus arvalis). J. Orn. 105: $247-306$.

Morton, M.I. and P.W. Sherman. 1978. Effects of a spring snowstorm on behavior, reproduction, and survival of Belding's ground squirrels. Can. J. Zool. 56:2578-2590.

Odum, E.P. and E.J. Kuenzler. 1955. Measurement of territory and home range size in birds. Auk $72: 128-137$.

Olendorff, R.R. 1974. Some quantitative aspects of growth in three species of Buteos. Condor 76,466-468.

Olendorff, R.R. and J.W. Stoddart. 1974. The potential for management of rapt or populations in western grasslands. Pp. 47-88. In Management of raptors. Raptor Research Foundation, Inc. Raptor Res. Rep. No. 2 .

Picozzi, N. and D. Wier. 1974. Breeding biology of the buzzard in Speyside. Brit. Birds 67:199-210.

Pitelka, F.A., P.Q. Tomich, and G.W. Treickel. 1955. Breeding behavior of jaegers and owls near Barrow, Alsaka. Condor 57:3-18.

Schmaus, A. 1938. Der Einfluss der Mausejahre auf das Bruteschaft unserer Raubvogel und Eulen. Beitr. Fortpfl. Biol. Vogel 14:181-184. Cited in Klomp 1970.

Smith, D.G. and J.R. Murphy. 1973. Breeding ecology of raptors in the eastern Great Basin of Utah. BYU Sc1. Bull. 18(3).

Southern, H.N. 1959. Mortality and population control. Ibis 101: 429-436.

Southern, H.N. 1970. The natural control of a population of Tawny Owls (Strix aluco). J. Zool. 162:197-285. 
Tubbs, C.R. 1967. Population study of buzzards in the New Forest during 1962-1966. Brit. Birds 60:381-395.

Turner, G.T., R.M. Hansen, V.H. Reid, H.P. Tiet jen, and A.L. Ward. 1973. Pocket gophers and Colorado mountain rangeland. Colorado State University Exp. Sta. Bull. 544S.

Turnex, L.W. 1972. Autecology of the Belding's ground squirrel in Oregon. PhD. thesis. University of Arizona, Tucson.

USDI Bureau of Land Management. 1979. Snake River bird of prey special research report. 